\title{
PERSONAL FACTORS AS PREDICTORS OF INTENTION TO USE IT
}

\author{
Tutuk Ari Arsanti ${ }^{*}$, Emalia Yuliasari ${ }^{2}$ \\ ${ }^{1,2}$ Universitas Kristen Satya Wacana, Salatiga 50711, Indonesia \\ *Corresponding author; Email: tutuk.arsanti@staff.uksw.edu
}

\begin{abstract}
The relative power of personal factors such as innovativeness, perceived usefulness, ease of use, and attitude in predicting intention to use IT was tested with 35 students through a field experiment. A common employment website in Indonesia called jobstreet. com is used as a treatment channeling instrument as well as relevant audio and visual media. Simple and multiple regression were used to test the hypotheses. Our findings show that the personal factors such as personal innovation could predict perceived ease of use better than perceived usefulness. The other personal factors such as individual perception (perceived ease of use and perceived usefulness) could predict attitude for the next to effect intention to use IT.
\end{abstract}

Keywords: Personal innovation, perceived usefulness, perceived ease of use, attitude, intention to use.

\section{Introduction}

The desire to use information technology (IT) is referred to as an 'intention to use IT'. The intention to use IT is influenced by the potential user's attitude. Research conducted by Ko, Pei, and Tsai (2016) revealed that the attitude formed in an individual is built by a particular motivation that is selected and interpreted, which is known as an individual (personal) perception. The personal perception which builds an attitude in an individual is an individual's perception towards the advantages (perceived usefulness) and ease (perceived ease of use) in using IT (Davis, Bagozzi, \& Warshaw, 1989). In other words, when an individual has a positive perceived usefulness and perceived ease of use, it can influence an individual's attitude (Bhattacherjee, 2000; Lin, 2006 \& 2010; Sayid \& Echchabi, 2013; Hsu, 2016). This positive attitude by the individual will affect the person's intention to use IT (Bhattacherjee, 2000; Lin, 2006 \& 2010; Susanti \& Gunarsih, 2008; Hsu, 2016).

Previous research about the technology acceptance model (TAM) reveals that personal factors such as perceived usefulness, perceived ease of use, and attitude influence one's intention to use technology. However, this research has not paid much attention to personal innovativeness, which is different from one individual to the next. Research conducted by Yi, Fiedler, and Park (2006); and Zarmpou, Saprikis, Markos, and Vlachopoulou (2012) showed that an individual's personal innovativeness can impact the perceived usefulness and perceived ease of use. Differences in innovativeness can affect how an individual perceives something. Personal innovativeness can be defined as to what extent an individual wants to try something new. An individual who has high personal innovativeness will tend to form a positive perception towards IT. Thus, a person with high personal innovativeness will tend to have a positive perception towards the benefits and uses of IT, which can then affect one's attitude to want to use technology.

Technological developments like IT as a media recruitment started to shift from traditional recruitment to online recruitment. Mondy (2008) mentioned that online recruitment has revolutionized the way companies recruit employees, jobseekers, and job applicants, because of the numerous advantages that can be obtained (Bartram, 2000). In their research, Ghazzawi and Accoumeh (2014) mentioned that by having new technology, it can quicken and facilitate the recruitment process. Thus, online recruitment technology will be far more effective and efficient, such as the time will be shorter, the costs will be lower, and jobseekers will receive information more easily about their desired job vacancies. With the development of IT, this research will explore how to see personal factors like personal innovativeness, personal perception, and attitude to explain intention to use IT like for online recruitment. This research utilized a field experiment on a number of vocational high school students with online recruitment technology such as jobstreet.com.

This research was conducted to analyze personal factors, such as personal innovativeness, personal perception, and attitude in explaining intention to use IT. This research provides insight into understanding the influences of personal factors on one's intention to use IT.

\section{Innovativeness Influence on Perceived Usefulness and Ease of Use}

Personal innovativeness here depicts to what level an individual is willing to try new information 
technology by engaging in positive beliefs towards using information technology (Agarwal \& Prasad, 1998; Yi et al., 2006). Meanwhile, Aisyah, Nugroho, and Sagoro (2014) mentioned that personal innovativeness is viewed as a trait or characteristic that will influence using a system through one's relationship with a perception of the technology. A perception can be obtained by using one's senses, which every individual possesses to receive information that is then selected and then partially organized after being interpreted. As clarified by Wibowo (2013), perception is an organizing process which facilitates us in organizing information and interpreting messages about our surrounding environment. Therefore, by having differences between people, it allows for different perceptions among them as well. An individual who has high personal innovativeness will tend to think positively about a new innovation. This is in line with research conducted by Zarmpou et al. (2012), who discovered that when an individual has high personal innovativeness, it will produce positive perceptions.

In the technology acceptance model, there are two perception constructs, which are perceived usefulness and perceived ease of use, according to Davis et al. (1989), who defined perceived usefulness as the level where an individual believes that using the proper system will increase the individual's ability. Yi et al. (2006) also explained that users who have a high level of innovation will understand more about the advantages of IT, so that they believe in themselves and in the uses of IT. So, from that explanation, it can be found that the higher a person's personal innovativeness is, the more positive the perceived usefulness is in IT.

Perceived ease of use is defined as the level where an individual believes that using the right new technology system will be easy to use (Davis et al., 1989; Lin, 2010). Thus, when an individual has personal innovativeness, that individual will perceive that a certain kind of technology is easy to use and be applied. The bigger personal innovativeness is, the higher the perceived ease of IT use is. It is also the same the other way around; when a person does not want to engage in personal innovativeness, then the individual will have a low level of perceived ease of IT use. It research conducted by Utama, Wibowo, and Nurhadi (2014), similar research was also found in that personal innovativeness can influence perceived ease of use.

$H_{l}$ : Personal innovativeness will positevely influence perceived usefulness.

$\mathrm{H}_{2}$ : Personal innovativeness will positevely influence perceived ease of use.

\section{Impact of Usefulness and Ease of Use on Attitude}

An individual who prepares a technology positively will provide a stimulus or re-action in the form of a positive value or attitude (Ko et al., 2016). Taylor and Todd (1995) defined an attitude as being connected with the role of a positive evaluation or negative evaluation of an individual in using a kind of technology. So an attitude is an individual's general feeling of an evaluative response, which is in the form of a positive or negative impression, good or bad towards a certain object.

In an IT context, it can be shown that an individual's attitude to use a new kind of technology will be influenced by how the user perceives the advantages that can be obtained. This is in line with research conducted by Sayid and Echchabi (2013) about mobile banking service in Somalia with 100 respondents. They found results that perceived usefulness has a positive significant influence towards an individual's attitude. The perception of advantages produced from new technology will provide a positive attitude for potential users. Research results by Sayid and Echchabi (2013) are consistent with research results found by Bhattacherjee (2000), Lin (2006 \& 2010), and Hsu (2016), who showed that perceived usefulness has a significant influence on an individual's attitude.

Hsu (2016) stated that the higher the perceived ease of use is, then the more positive an individual's attitude will be. Lin (2010) conducted research with 174 participants who were seeking jobs in Taiwan. Lin found that when jobseekers understand that by using a job search website, it will facilitate them in applying for jobs and result in positive attitudes for the jobseekers. The higher the perceived ease of use is, the better the attitude produced will be. Based on this research, it shows that an individual's attitude in accepting new technology is greatly influenced by the perceived ease of use, like in research conducted by Bhattacherjee (2000), Lin (2006 \& 2010), and Hsu (2016).

$H_{3}$ : Perceived Usefulness will positively influence Attitude

$H_{4}$ : Perceived Ease of Use will positively influence Attitude

\section{Impact of Attitude on Intention To Use IT}

Intention to use, according to Davis et al. (1989), is the tendency for an individual to want to use a certain kind of technology. The level of using a new kind of technology by an individual can be predicted from the person's attitude and attention towards that 
technology to be used (Davis et al., 1989). An individual who has a positive attitude tends to want to use a new type of technology. Susanti and Gunarsih (2008) mentioned that the more positive an individual's attitude is, the higher the person's desire will be in using that new technology. Based on the description above, it can be considered that an individual's attitude can influence one's intention to use IT. In research carried out by Bhattacherjee (2000), Lin (2006 \& 2010), and Hsu (2016). It was also discovered that one's attitude can influence one's intention to use IT.

$H_{5}$ : Attitude will positively influence Intention to Use

Based on the hypotheses that were formulated, the influences between variables can be depicted in the form of a research model as on Figure 1.

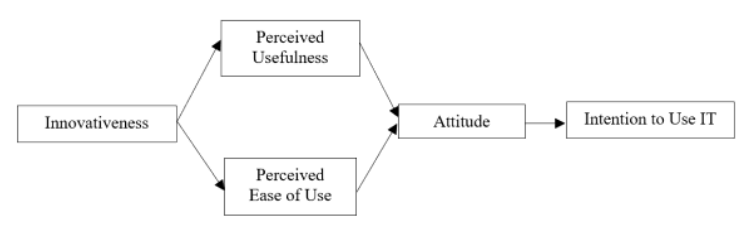

Figure 1. Research model

Source: Davis et al. (1989); Agarwal and Prasad (1998)

\section{Research Method}

The design used in this research is by using field experiments, because the researcher strives to see an individual's psychological reactions in a natural or actual setting. In this research, the researcher used a common employment website in Indonesia called jobstreet.com, as a treatment channeling instrument as well as relevant audio and visual media. Then it was shown to the participants to be used as an information, knowledge, and experience channel to be analyzed for personal factors, such as personal innovativeness and personal perception in the form of perceived usefulness, perceived ease of use, and attitude, in explaining their intention to use IT.

\section{Participants}

The researcher involved students from Public Vocational High School 1 Salatiga, as participants, where vocational high school graduates in general are prepared to work. In spite of this, based on initial interview results with the student guidance counseling office, they stated that the students had not been taught how to use online recruitment media at school. Therefore, this research used 35 students as participants to analyze their intention to use IT. The ex- periment of this class was divided into two sessions.

\section{Experiment Procedures}

The author has conducted field experiment on two sessions:

1. In this first session, the researcher explained about the goal of the activity that was conducted in class as well as the development of IT and its advantages in the recruitment process. Next, the participants were given questionnaires on personal innovativeness and instructions on how to fill it out. At the end of this session, the completed questionnaires were collected.

2. In the second session, the participants were given insight and experience in how to open an account, register an account, look for employment, choose a job, and send a job application in an employment agency website that is common in Indonesia called JobStreet.com. After the participants obtained knowledge and experiences from using the website Job-street.com, in the next stage, the researcher handed out questionnaires that were used to measure the perceived usefulness, perceived ease of use, attitude, and intention to use IT. After the researcher confirmed that all of the participants filled in the questionnaires completely and correctly, the participants were asked to handin the questionnaires.

\section{Measurement}

The instrument used to measure the variable personal innovativeness was adopted from Agarwal and Prasad (1998). Personal innovativeness was used to measure the level of willingness to try new information technology. A Likert scale of one to five was used with one being strongly do not agree (STS) and five being strongly agree (SS) to measure their attitudes, opinions, and perceptions. The measuring instruments perceived usefulness and perceived ease of use were adopted from Davis et al. (1989). A Likert scale of one (strongly do not agree) to five (strongly agree) was also used for these variables. The measuring instruments attitude and intention to use were adopted from Taylor and Todd (1995). Attitude was used to find out the user's attitude towards IT, while intention to use was applied to discover one's interest in using IT such as JobStreet.com, as an online recruitment media. Similar with the other variables, a Likert scale of one (strongly do not agree) to five (strongly agree) was also used for these variables. 
A validity test of all the variables can be seen with an $r_{\text {count }}>r_{\text {table }}$ with $d f=n-2$ and $\alpha=0.05$, so that an $r_{\text {table }}$ is obtained with a value of 0.2826 . Based on a validity test of all the measuring instruments, it can be stated that it is valid and can be used to retrieve data in this research. More detailed results can be found in the Table 1 to Table 5.

Table 1

Validity Test of Personal Innovativeness

\begin{tabular}{lcccc}
\hline & No Item & $\boldsymbol{r}_{\text {test }}$ & $\boldsymbol{r}_{\text {table }}$ & Validity \\
\hline Personal & IN_1 & 0.777 & 0.2826 & Valid \\
Innovativeness & IN_2 & 0.828 & & Valid \\
& IN_3 & 0.627 & & Valid \\
& IN_4 & 0.759 & & Valid \\
\hline
\end{tabular}

Table 2

Validity Test of Perceived Usefulness

\begin{tabular}{lllll}
\hline & \multicolumn{2}{l}{ No Item rtest } & rtable & Validity \\
\hline Personal & PU_1 & 0.814 & 0.2826 & Valid \\
Usefulness & PU_2 & 0.806 & & Valid \\
& PU_3 & 0.774 & & Valid \\
& PU_4 & 0.495 & & Valid \\
\hline
\end{tabular}

Table 3

Validity Test of Perceived Ease of Use

\begin{tabular}{lcccc}
\hline & No Item & $\boldsymbol{r}_{\text {test }}$ & $\boldsymbol{r}_{\text {table }}$ & Validity \\
\hline Perceived & PEU_1 & 0.716 & 0.2826 & Valid \\
Ease of Use & PEU_2 & 0.705 & & Valid \\
& PEU_3 & 0.635 & & Valid \\
& PEU_4 & 0.689 & & Valid \\
\hline
\end{tabular}

Table 4

Validity Test of Attitude

\begin{tabular}{lcccc}
\hline & No Item & $\boldsymbol{r}_{\text {test }}$ & $\boldsymbol{r}$ table & Validity \\
\hline Attitude & ATT_1 & 0.717 & 0.2826 & Valid \\
& ATT_2 & 0.632 & & Valid \\
& ATT_3 & 0.627 & & Valid \\
& ATT_4 & 0.836 & & Valid \\
\hline
\end{tabular}

Table 5

Validity Test of Intention to Use

\begin{tabular}{lcccc}
\hline & No Item & $\boldsymbol{r}_{\text {test }}$ & $\boldsymbol{r}_{\text {table }}$ & Validity \\
\hline Intention to & ITU_1 & 0.679 & 0.2826 & Valid \\
Use & ITU_2 & 0.754 & & Valid \\
& ITU_3 & 0.832 & & Valid \\
\hline
\end{tabular}

Based on the reliability test results, the Cronbach's Alpha personal innovativeness is 0.726, the perceived usefulness is 0.620 , the perceived ease of use is 0.689 , the variable attitude is 0.658 , and the variable intention to use is 0.615 . With the Cronbach's Alpha $>0.6$, the measuring instrument that will be used is considered reliable, so that it can be used for data retrieval in this research.
The data analysis that used in this research involves a descriptive analysis instrument to obtain a general depiction of the personal factors from the participants. Meanwhile, to analyze the hypotheses developed, a simple regression and double regression are used to find out the influences between the free variables and connected variables. Nevertheless, before the data is processed and analyzed further, a classic assumption test is done first with a normality test that is used for all variables, while a heteroscedasticity test and a multicolinearity test are only used for the variables perceived usefulness, perceived ease of use, and attitude. The data analysis uses an SPSS 20.0 for Windows program.

A descriptive analysis is used to find a general depiction of the participants' answers regarding personal innovativeness, perceived usefulness, perceived ease of use, attitude, and intention to use, which are produced by the responses from the treatments given (Sugiyono, 2013).

Total core per item indicators

Score average $=$ n

Total score item indicators

$$
\text { Total score average }=\text {------------------- }
$$

Meanwhile, the range for every variable uses the highest score of five and the lowest score of one with a total of 35 respondents. Based on the calculation formula, the average total score range obtained is 28 , so that:

$$
\begin{array}{ll}
35-62.99 & =\text { Very low } \\
63-90.99 & =\text { Low } \\
91-118.99 & =\text { Average } \\
119-146.99 & =\text { High } \\
147-175 & =\text { Very high }
\end{array}
$$

\section{Result and Discussion}

Based on the statistics results, it shows that the variables personal innovativeness, perceived ease of use, and intention to use IT are each 130.5, 134, 145, and 140, where all of the values are in the range of 119-147 in the high category. Meanwhile, for the variable perceived usefulness, the average value is 152.5 , which is in the range of $147-175$, which is categorized as very high. Thus, in general it can be depicted that the participants have a high intention to use IT, which is also caused by their personal factors like innovativeness, perceived ease of use, attitude towards IT (high desire to use the website jobstreet. com), and very high perceived usefulness. The hypotheses that were developed to be analyzed by a 
simple regression were for Hypotheses 1, 2, and 5 . Meanwhile, a double regression was used for hypothesis 3 and Hypothesis 4.

\section{Hipothetical Tests}

According to the simple regression analysis result in Table 6, it shows that Hypothesis 1 is rejected, because the level of significance is more than five percent or a sig. of $0.328>0.05$. Therefore, there is no significant influence between personal innovativeness towards perceived usefulness. Meanwhile, Hypothesis 2 and Hypothesis 5 are accepted with a significance level less than five percent or a sig. of < 0.05 , with each being 0.035 and 0.000 . Thus, there is a significant influence between personal innovateveness and attitude towards intention to use IT.

According to the multiple regression analysis result in Table 7, it shows that multiple regression results have an influence of perceived usefulness and ease of use towards attitude, which is accepted with a significance level of less than five percent or $0.000<$ 0.05 . Meanwhile, there is a partial influence of perceived usefulness towards attitude with $0.012<0.05$, and there is a partial influence of perceived ease of use towards attitude with $0.026<0.05$. Thus, it can be clarified that there is a significant impact between perceived usefulness and perceived ease of use towards attitude partially or simultaneously.

Table 6

Simple Regression

\begin{tabular}{lccc}
\hline & $\boldsymbol{B}$ & $\boldsymbol{T}$ & Sig \\
\hline Independent variable: & 0.170 & 0.993 & 0.328 \\
Personal Innovativeness & & & \\
Dependent Variable: & & & \\
Perceived Usefulness & & & \\
$F=0.986$ & & & \\
$R^{2}=0.29$ & & & \\
Independent variable: & 0.357 & 2.194 & 0.035 \\
Personal Innovativeness & & & \\
Dependent variable: & & & \\
Perceived Ease of Use & & & \\
$F=4.813$ & & & \\
$R^{2}=0.127$ & & & \\
Independent variable: & 0.572 & 4.011 & 0.000 \\
Attitude & & & \\
Dependent variable: Intention & & & \\
to Use & & & \\
$F=16.089$ & & \\
$R^{2}=0.328$ & & \\
$\alpha=5 \%$ & & \\
\hline
\end{tabular}

Table 7

Multiple Regression Analysis

\begin{tabular}{lccc}
\hline & $\boldsymbol{B}$ & $\boldsymbol{T}$ & Sig \\
\hline Independent variable: & 0.432 & 2.652 & 0.012 \\
Perceived Usefulness & & & \\
Dependent variable: & & & \\
Attitude & & & \\
Independent variable: & 0.380 & 2.337 & 0.026 \\
Perceived Ease of Use & & & \\
Dependent variable: & & & \\
Attitude & & & \\
$F=20.275$ & & & \\
Sig $=0.000$ & & & \\
$R^{2}=0.559$ & & & \\
$\alpha=5 \%$ & & & \\
\hline
\end{tabular}

\section{Discussion}

The rejected of the first hypothesis means that there is no influence in an individual's level of willingness to try online recruitment towards the perception of usefulness of online recruitment. These research results can occur due to several possibilities in vocational high school students that in general are prepared to work through their curriculum. This condition facilitates vocational high school students to have an orientation to look for employment after they graduate. Thus, automatically the need to look for employment, whether done in a traditional way or online, is made easier to do. This need can better explain the perception of advantage and ease of online recruitment technology like jobstreet.com.

Another possibility that can explain the rejection of Hypothesis 1 is that theoretically the vocational high school students' characteristics are classified as part of the Y generation, where Bassett (2008) considers the $\mathrm{Y}$ generation as being clever in using technology. Besides that, it is also considered as a technology friendly generation, so that they are easy to communicate with other people and use technology to access information quickly. This makes the perceived usefulness of the participants explained not because of personal innovativeness but more because vocational high school students are included in the Y generation, which has a positive perception towards IT.

Another factor which is suspected to influence Hypothesis 1 being rejected is the weakness in providing treatment in this field experiment, in that the researcher in providing information and knowledge about IT to the participants emphasized the major benefits of IT, so that it potentially could contribute to building the participants' perceived usefulness rather than their personal innovativeness. This is also seen in the statistics descriptive results table which reveals 
that personal innovativeness is in the high category, while perceived usefulness is in the very high category. Nevertheless, the results of the research towards Hypothesis 1 support research conducted by Walczuch, Lemmink, and Streukens (2007); Kuo and Yen (2009); and Aisyah et al. (2014), who stated that there is no influence of personal innovativeness on perceived usefulness.

In the second hypothesis, the statistical test results show that personal innovativeness has a significant effect on perceived ease of use. Thus, the greater an individual's desire is to try online recruitment, an individual's perception will have a greater influence on ease in using on-line recruitment. It is also the same the other way around. Strong personal innovativeness will result in a perception of comfort and ease in using a kind of technology. In a condition like today where the IT era facilitates many tasks or activities to be done through IT, it enables the participants to be more familiar with using computers, the Internet, and other IT technology. These research results are in line with previous research that personal innovativeness has an influence towards perceived ease of use (Lewis, Agarwal, \& Sambaburthy, 2003; Yi et al., 2006; Walczuch et al., 2007; Kuo and Yen, 2009; Zarmpou et al., 2012; Utama et al., 2014; Aisyah et al., 2014).

In the third hypothesis, the test results statistically show that perceived usefulness significantly influences attitude. Therefore, an individual who has a perception that IT has many advantages will also build a positive attitude. According to Lin (2010), in an online recruitment service context, the perception of IT advantages conveys jobseekers' trust in their ability to acquire current career information, improve their effectiveness in searching for employment, and increase their opportunities to find the right jobs when using a job search website. Besides that, Braddy, Meade, and Kroustalis (2008) also stated that when job seekers think about the advantages of using a recruitment website, it will be more beneficial or interesting and considered as a kind of potential job providing media.

Likewise, in this research, when participants perceive that online recruitment provides them with advantages in searching for employment, it will help them develop a positive attitude towards online recruitment technology. A positive attitude here is an encouraging reaction or response by the participants who are interested in or enthusiastic with online recruitment. Thus, the participants' attitudes to use online recruitment will be supported by how the participants perceive the various benefits that they may obtain. This research is in line with the results of previous research that was conducted by Bhattacherjee (2000), Lin (2006 \& 2010), Sayid and Echchabi (2013), and Hsu (2016).

In the fourth hypothesis, the test results statistically reveal that perceived ease of use has a significant influence on attitude. This result is compatible with that found in the previous section, in that the greater an individual perceives ease in using a kind of technology, it will build a positive attitude towards that technology. By building the participants' perception about the ease in using online recruitment technology to apply for jobs, it will result in a positive attitude to want to use it. In this research, the participants were provided with experience in using jobstreet.com by providing them with instructions in how to use it through showing a video that explained in detail about how to use jobstreet.com.

In this experiment, the participants practiced how to open the website, register for an account, look for employment, choose a job, and send job applications through jobstreet.com. These research results show that the participants perceived online recruitment technology as having high ease of use, so that this influenced them in forming a positive attitude towards the technology itself. These research results are in line with previous research carried out by Ghazzawi, Al-Khoury, and Saman (2014). In their research, they discovered that when someone thinks that a particular kind of technology is easy and straightforward to use, it will cause a better or more positive attitude towards that technology. These research results are also in line with research conducted by Lee (2009), Bhattacherjee (2000), Lin (2006 \& 2010), and Hsu (2016), in that perceived ease of use has an influence on attitude.

In the fifth hypothesis, the research results statistically reveal that attitude has a significant influence on intention to use IT. The more positive an individual's attitude is in evaluating online recruitment technology, the more that individual will want to use it. This is in line with Davis et al. (1989), who found that an individual's degree of using a new kind of technology can be predicted from the person's attitude towards that technology to still want to use it. Having a positive attitude towards an online recruitment technology will influence an individual's desire to use that technology and the other way around. Susanti and Gunarsih (2008) also claim that the more positive someone's attitude is towards IT, the higher the person's desire will be to use it. These research results are consistent with previous research, which declares that the more positive a person's attitude is towards IT, then the greater intention one will have to use IT (Bhattacherjee, 2000; Lin, 2006 \& 2010; Hsu, 2016). 


\section{Conclusions and Implications}

\section{Conclusions}

1. This reveals that there is no influence bet-ween an individual's desire to try IT with building a perception of the benefits of the IT.

2. These results indicate that the higher a participant's willingness is to try information technology, then it will foster a perception of ease in using its application.

3. The greater a person perceives the advantages of IT are, the more positive of an attitude will be produced.

4. The greater an individual perceives ease in using IT, a more positive attitude will be produced.

5. One's attitude has a significant influence on one's intention to use. The more positive a person's attitude is in evaluating IT, the more interested the individual will be in using the technology.

\section{Practical Implication}

These research results can provide information to schools about the importance of building positive perceptions and positive attitudes in their students towards online recruitment as an Information Technology, so that it can influence their willingness to use it.

\section{Theoretical Implication}

Previous research explained about how personal innovativeness has an influence on perceived usefulness of IT. In spite of that, in this research, it is not supported. Although these re-search results show that the coefficient values of the innovativeness variable are positive, it does not prove there is a significant influence. This can be explained with the possibility that the participants are classified as part of the $\mathrm{Y}$ generation, which tends to be more technologically oriented, so that it may have a more dominant influence on perceived usefulness towards IT rather than an individual innovativeness factor. Thus, the field experiment research conducted was not able to stimulate personal innovativeness and its influence towards perceived usefulness. Using other technology which is unfamiliar for participants may provide different results in an experimental research.

\section{References}

Agarwal, R., \& Prasad, J. (1998). A conceptual and operational definition of personal innovativeness in the domain of information technology. Information Systems Research, 9(2), 204-215.
Aisyah. N. M., Nugroho, M. A., \& Sagoro, E. M. (2014). Pengaruh technology readiness terhadap penerimaan teknologi komputer pada umkm di Yogyakarta. Jurnal Economia, 10(2), 105-119.

Bartram, D. (2000). Internet recruitment and selection: Kissing frogs to find princes. International Journal of Selection and Assessment, 8(4), 261274.

Bassett, B. (2008). Working with generation y. Office Pro, 68(2), 16-19.

Bhattacherjee, A. (2000). Acceptance of internet applications services: The case of electronic brokerages. IEEE Transactions on Systems, Man, and Cybernetics - Part A: Systems and Humans, 30(4), 411-420.

Braddy, P. W., Meade, A. W., \& Kroustalis, C. M. (2008). Online recruiting: The effects of organizational familiarity, website usability, and website attractiveness on viewers impressions of organizations. Computers in Human Behavior, 24, 2992-3001.

Davis, F. D., Bagozzi, R. P., \& Warshaw, P. R. (1989). User acceptance of computer technology: A comparison of two theoretical models. Management Science, 35(8), 982-1003.

Ghazzawi, K., \& Accoumeh. A. (2014). Critical success factors of the e-recruitment system. Journal of Human Resources Management and Labor Studies, 2(2), 159-170.

Ghazzawi, K., Al-Khoury, P., \& Saman. J. (2014). The effect of implementing technology in hrm on the level of employee motivation. Human Resource Management Research, 4(2), 33-39.

Hsu, M. W. (2016). An analysis of intention to use in innovative product development model through tam model. Eurasia Journal of Mathematics, Science \& Technology Education, 12(3), 487501.

Ko, C. H., Pei, L., \& Tsai, Y. H. (2016). A study of employees' perception of information technology adoption in hotels. International Journal of Organizational Innovation, 8(3), 231-238.

Kuo. Y. F., \& Yen. S. N. (2009). Towards an understanding of the behavioral intention to use $3 \mathrm{G}$ mobile value-added services. Computers in $\mathrm{Hu}$ man Behavior, 25(1), 103-110.

Lee. M. C. (2009). Predicting and explaining the adoption of online trading: An empirical study in Taiwan. Decision Support Systems, 47, 133142.

Lewis, W., Agarwal. R., \& Sambaburthy, V. (2003). Sources of influence on beliefs about information technology use: An empirical study of knowledge workers. MIS Quarterly, 27(4), 657678. 
Lin, H. F. (2006). Understanding behavioral intention to participate in virtual communities. Cyber Psychology and Behavior, 9(5), 540-547.

- (2010). Applicability of the extended theory of planned behavior in predicting job seeker intentions to use job search websites. International. Journal of Selection and Assessment, 18(1), 64-74.

Mondy, R. W. (2008). Manajemen sumber daya manusia. Jilid 1 Edisi 10. Jakarta: Erlangga.

Sayid, O., \& Echchabi, A. (2013). Attitude of Somali customers towards mobile banking services: The case of Zaad and Sahal services. Economic Insights - Trends and Challenges, II/LXV(3), 9 16.

Sugiyono. (2013). Metode penelitian kuantitatif, kualitatif dan $r \& d$. Bandung: Alfabeta.

Susanti, Y., \& Gunarsih, T. (2008). Pengaruh sikap terhadap perilaku, faktor sosial dan kontrol keperilakuan yang dirasakan terhadap minat pembelian tiket pesawat secara online. A paper presented on National Conference on Management Research 2008, Makassar, Indonesia.
Taylor, S., \& Todd, P. A. (1995). Understanding information technology usage: A test of competing models. Information Systems Research, 6(2), 144-176.

Utama, A., Wibowo, A., \& Nurhadi. (2014). Pengaruh faktor individu terhadap keyakinan manfaat menggunakan teknologi informasi. Jurnal Economia, 10(2), 177-186.

Walczuch, R., Lemmink, J., \& Streukens, S. (2007). The effect of service employees' technology readiness on technology acceptance. Information \& Management, 44, 206-215.

Wibowo. (2013). Perilaku dalam organisasi. Edisi 2. Jakarta: Rajawali Pers.

Yi, M. Y., Fiedler, K. D., \& Park, J. S. (2006). Understanding the role of individual innovativeness in the acceptance of it-based innovations: Comparative analyses of models and measures. Decision Sciences Institute, 37(3), 393-426.

Zarmpou, T., Saprikis, V., Markos, A., \& Vlachopoulou, M. (2012). Modeling users' acceptance of mobile services. Electronic Commerce Research, 12(2), 225-248. 